\title{
Piotr Majer, Ustawy policji polskiej (1791-1990). Źródła z komentarzem, Wydawnictwo Marszałek, Toruń 2007.
}

Recenzowana praca ma postać zbioru aktów prawnych związanych z wykonywaniem funkcji policyjnej państwa na ziemiach polskich, zarówno w okresie niepodległego bytu państwa polskiego, jak też w warunkach ograniczonych form suwerenności czasu rozbiorów i powstań narodowych. Pierwszy człon tytułu nie jest do końca precyzyjny, gdyż książka zawiera normy prawa stanowionego, powołujące polskie organy policyjne oraz określające ich kompetencje i miejsce wśród innych organów państwa. Jak słusznie zauważa autor, w polskich dziejach regulacje dotyczące policji występowały nie tylko w ustawach i dekretach, lecz także w aktach prawa stanowionego niższego szczebla - dekretach, okólnikach, instrukcjach i rozkazach.

Zakres prezentowanych źródeł ulega stopniowemu zawężeniu wraz z ewolucją pojęcia policji na ziemiach polskich, które to pojęcie zyskało rację bytu w drugiej połowie XVIII w. wraz z kształtowaniem się podstaw nowoczesnej administracji ${ }^{1}$. Jako cezurę czasową pracy autor przyjmuje uchwalenie przez Sejm Wielki pierwszej polskiej ustawy policyjnej - o Komisji Policji Obojga Narodów, która oprócz funkcji związanych z zapewnieniem porządku publicznego wykonywała także zadania z zakresu administracji spraw wewnętrznych. Szerokie potraktowanie przez autora terminu policja powoduje, że część pracy obejmująca schyłkowy okres państwowości polskiej i czas rozbiorów zawiera źródła nie tylko bezpośrednio policyjne, lecz także dotyczące administracji centralnej i terenowej we fragmentach dotyczących policji w ówczesnym tego słowa znaczeniu. Wśród tych źródeł zabrakło jednak uchwalonej przez Sejm Grodzieński w 1793 r. ustawy o Komisji Policji, która została zamieszczona w tomie X Volumina Legum.

Sytuując genezę polskiej policji w drugiej połowie XVIII wieku autor próbuje obalić pogląd wiążący początki polskiej policji z powołaniem w lipcu w 1919 r. korpusu Policji Państwowej ${ }^{2}$, lecz nie czyni tego w sposób przekonujący. Obchodzenie rocznicy tego wydarzenia jako Święta Policji w dzisiejszym tego słowa znaczeniu stanowi konsekwencję powszechnie przyjętego w XX w. ograniczenia zadań policji do ochrony spokoju,

1 Termin policja wywodzony jest od greckiego słowa „politea”, oznaczającego zarząd państwem i początkowo był kojarzony z ogółem funkcji państwowych. Na przełomie XVII i XVIII w. nastąpiło zawężenie tego pojęcia do wykonywania administracji w szerokim tego słowa znaczeniu. Pod wpływem idei prawa natury głoszonej przez doktrynę liberalną policja jako funkcja państwa była ograniczana w swej omnipotencji. Obok funkcji policyjnej pojawiły się w XVIII w. określone dziedziny działalności rzeczowej państwa w postaci spraw zagranicznych, skarbowych, wojskowych, a wreszcie wewnętrznych. Nowa organizacja aparatu państwowego zawęziła zakres pojęciowy terminu policja, który zaczął nabierać współczesnego znaczenia, czyli funkcji państwa polegającej na ochronie lub przywracaniu bezpieczeństwa, porządku i spokoju publicznego, także przy wykorzystaniu środków przymusu bezpośredniego. H. Izdebski, Historia administracji, Warszawa 1996, s. 30.

2 Ustawą z dnia 24 lipca 1919 r. o Policji Państwowej (Dziennik Praw Państwa Polskiego z 1919 r., Nr 61, poz. 363) 
bezpieczeństwa i porządku publicznego. Słuszności tego kroku autor nie kwestionuje, gdyż począwszy od czasów II Rzeczypospolitej przedmiotem prezentacji są akty prawa stanowionego bezpośrednio związane z tytułową formacją.

Praca składa się z czterech części, których podstawowym wyróżnikiem są kolejne formy ustrojowe polskiej państwowości, czyli I Rzeczpospolita, II Rzeczpospolita, Polska Ludowa i III Rzeczpospolita. Każda z tych części jest poprzedzona wprowadzeniem, którego celem jest ogólna charakterystyka dziejów polskiej policji w wyróżnionym okresie. Wewnątrz poszczególnych części starano się zachować układ chronologiczny, od czego autor odstępuje przy prezentacji źródeł z okresu II RP. Wyróżniono tam na wstępie akty normatywne kształtujące centralne organy policyjne, by następnie przedstawić regulacje będące następstwem ujednolicania terytorialnego Polski ${ }^{3}$ Tę cześć pracy wieńczą dwa rozporządzenia Krajowej Rady Ministrów z dnia 1 sierpnia 1944 r. Zostały one zamieszczone w podstawowej części pracy, mimo że de facto nie weszły nigdy w życie, o czym przesądziły uwarunkowania polityczne. Części pracy poświęcone Polsce Ludowej i III Rzeczypospolitej mają jednolitą, prostą, chronologiczną konstrukcję. Ponadto książka posiada aneks zawierający pięć źródeł ${ }^{4}$, które zdaniem autora z różnych powodów nie kwalifikowały się do zamieszczenia w podstawowej części pracy, niemniej trudno byłoby je pominąć bez szkody dla komplementarności pozycji.

Znacząca część prezentowanych źródeł była wcześniej ogłoszona w różnych wydawnictwach, jakie ukazywały się zarówno w okresie międzywojennym, jak i powojennym. Zasługą autora jest zebranie tych dokumentów w jednym zbiorze umiejętnie łączącym historię z teraźniejszością, gdyż prezentacje źródeł kończy obowiązująca obecnie ustawa o Policji z dnia 6 kwietnia 1990 r. ${ }^{5}$ Nowością na tle dotychczas opublikowanych dokumentów są dwa źródła z okresu Rzeczypospolitej Krakowskiej oraz zarządzenie z dnia 17 grudnia 1939 r. ustalające zasady organizacyjne tzw. policji granatowej w Generalnym Gubernatorstwie. Oprócz ciekawych materiałów źródłowych godnym podkreślenia walorem recenzowanej pozycji jest prezentacja dziejów polskiej policji w ujęciu historycznoprawym, która jest zawarta we wprowadzeniach do poszczególnych części pracy.

Marcin Łysko

3 Celem przedstawienia procesu kształtowania Policji Państwowej w ujęciu organizacyjno-terytorialnym autor zamieścił źródła poświęcone tworzeniu policji w okresie bezpośrednio po odzyskaniu niepodległości na terytorium Galicji, Wielkopolski, Pomorza, Górnego Śląska i Ziem Wschodnich.

4 Trzy pierwsze źródła zamieszczone w aneksie związane są z Generalnym Gubernatorstwem, gdzie funkcje policyjne wypełniała m.in. tzw. policja granatowa, stanowiąca kontynuacje Policji Państwowej II RP. Kolejne źródło to dekret PKWN o ustanowieniu MO z lipca 1944 r., który ostatecznie nie wszedł w życie. Aneks kończy się projektem dekretu - najpewniej z końca 1945 r. - dotyczącego Ministerstwa Bezpieczeństwa Publicznego, faktycznie centralnego organu powojennej policji politycznej.

5 Dz. U. Nr 30, poz. 179. 